\title{
Applying Lithium-Ion Second Life Batteries for Off-Grid Solar Powered System-A Socio-Economic Case Study for Rural Development
}

\author{
Joern Falk ${ }^{1}$ - Antonio Nedjalkov ${ }^{1,2}$ - Martin Angelmahr ${ }^{1}$ - Wolfgang Schade W $^{1,2}$
}

Published online: 27 March 2020

(c) The Author(s) 2020

\begin{abstract}
Socio-economic development in the rural regions of Africa cannot succeed without suitable infrastructure. An essential key to this is electrification. Despite various national and international activities and expansion programmes, and a wide variety of actors, their implementation is progressing slowly. In order to supply remote areas with electricity, off-grid system technologies have become increasingly common in recent years. In this article, we present the use of a photovoltaic system in conjunction with a $85 \mathrm{kWh}$ second life lithium-ion battery (LIB) as an off-grid hybrid system to electrify an island in Lake Victoria in Tanzania as a socio-economic case study.

This off-grid hybrid system was able to supply an average of $42.31 \mathrm{kWh}$ of energy per day, with the daily demand of the key infrastructure successfully connected in the project, such as the local hospital and school, amounting to $18.75 \mathrm{kWh}$. The scaled annual production of $15,443.16 \mathrm{kWh}$ offers enough potential to include private households as well as the local fishing industry in the power supply. Assuming an expected lifetime of 15 years, the described system amortises itself from the 4th year. In addition, this project should also serve as a possible second life scenario for batteries with regard to the rapidly developing global electromobility and the perspective return of used LIBs. An economic and an ecological evaluation shows a solution approach of using a second life lithium-ion battery compared to a conventional diesel generator solution. The consideration of health aspects is included in the evaluation.
\end{abstract}

Keywords Off-grid · Mini-grid PV · Second life of lithium-ion battery (LIB) - Sustainable energy · Circular economy · Techno-socio-economic aspects assessment · Energy in developing countries · Power generator replacement · Power solution for rural areas in sub-Saharan Africa

Joern Falk

joern.falk@hhi.fraunhofer.de

1 Fraunhofer Heinrich Hertz Institute HHI, Einsteinufer 37, 10587 Berlin, Germany
2 IEPT, Clausthal University of Technology, Am Stollen 19A, Goslar, Germany 


\section{Lithium-Ionen-Batterien in zweiter Lebensdauer für netzunabhängige Solaranlagen - Eine sozioökonomische Fallstudie für die ländliche Entwicklung}

\section{Zusammenfassung}

Eine sozioökonomische Entwicklung in den ländlichen Regionen Afrikas kann ohne geeignete Infrastruktur nicht gelingen. Ein wesentlicher Eckpfeiler hierfür stellt die Elektrifizierung dar. Trotz diverser nationaler wie internationaler Maßnahmen und Ausbauprogramme, unterschiedlichster Akteure, schreitet die Umsetzung nur langsam voran. Um abgelegene Gegenden dennoch mit Elektrizität zu versorgen, haben sich in den vergangenen Jahren verstärkt netzunabhängige Systemtechnologien durchgesetzt. In diesem Artikel zeigen wir den Einsatz einer Photovoltaikanlage in Verbindung mit einer $85 \mathrm{kWh}$ Second Life Lithium-Ionen-Batterie (LIB) als netzunabhängiges Hybridsystem, zur Elektrifizierung einer Insel im Viktoriasee in Tansania als sozioökonomisches Projekt. Mit diesem netzunabhängigen Hybridsystem konnte täglich durchschnittlich 42,31 kWh Energie geliefert werden, wobei der tägliche Bedarf der im Projekt erfolgreich angeschlossenen Schlüsselinfrastruktur, wie das lokale Krankenhaus und die Schule, 18,75kWh beträgt. Die skalierte Jahresproduktion von $15.443,16 \mathrm{kWh}$ bietet genug Kapazität, private Haushalte sowie die lokale Fischerei mit in die Stromversorgung einzubeziehen. In der Annahme einer erwarteten Lebensdauer von 15 Jahren kann sich das beschriebene System bereits ab dem 4. Jahr amortisieren. Darüber hinaus soll dieses Projekt auch in Hinblick auf die sich rasant entwickelnde globale Elektromobilität und dem perspektivischen Rücklauf gebrauchter LIB gleichzeitig als mögliches Second Life Szenario für Batterien dienen. Eine ökonomische wie ökologische Bewertung soll einen Lösungsansatz zur Verwendung einer Second Life LIB im Vergleich zu einer konventionellen Lösung eines Dieselgenerators zeigen. Die Betrachtung gesundheitlicher Aspekte fließt in die Beurteilung mit ein.

\section{Introduction}

\subsection{Motivation}

For the first time in 2017, the total number of people without access to electricity fell below the billion level (World Energy Outlook 2018, International Energy Agency [IEA 2018b]). Although, this is an important milestone worldwide, the situation in Africa remains precarious (Fig. 1). Particularly in the rural region south of the Sahara, more than 600 million people are still isolated from a comprehensive and reliable energy supply (United Nations 2018). Despite many energy resources, (Scholvin 2015), challenges remain great given $13 \%$ of the world's population currently lives in this region, but accounts only $4 \%$ of global consumption (Worldbank 2018). The lack of electrification remains one of the biggest obstacles to social and economic development (Wolde-Rufael 2006). However, there is also a need for households with electricity connections to operate expensive backup solutions for fossil fuels. In addition to the often unreliable supply, there are additional line losses, which are twice as high in global comparison due to an inadequately maintained network infrastructure on average. In addition, local electricity tariffs are often among the most expensive in the world (International Energy Agency 2014a). Despite international efforts and development programmes (Ponzano 2018), it can be assumed that the gaps in electricity coverage cannot be closed before 2038 (Bundesministerium für wirtschaftliche Zusammenarbeit und Entwicklung (BMZ) 2017b).
Within the project of the Africa Renewable Energy Initiative (AREI) renewable energy can be a key to accelerate and support (Gielen et al. 2016). According to the International Renewable Energy Agency (IRENA), renewable energy can cover half of Africa's electricity consumption by 2030 .

Since expansion of conventional grid systems networks is slow, this article focuses on the establishment of decentralized and local off grid solutions. Off grid systems can generate electricity on the basis of different technologies. In addition to conventional diesel generators, these include photovoltaic (PV) systems, wind systems and hydropower. Depending on the available resources, a combination of different systems is often used.

Off-grid systems can be adapted to the individual power requirements of the respective location and provide direct current as well as alternating current, single-phase or threephase. In addition, these systems can operate autonomously and can also be linked to the existing power network to close supply gaps.

This approach aims preventing the expansion of energy supply from contradicting agreed climate targets (UNFCCC 2015). In Fig. 2 the percentage of population with access to electricity is visualized. For the case study in this article the place of deployment is situated in Tanzania which is highlighted in red. According to World Bank's data 2016, $32.8 \%$ of Tanzania's population have access to electricity. Even though the overall situation has improved since 1990 when coverage was $2.5 \%$, great efforts are still needed to enable a nationwide power supply. In addition, there are still major differences in the degree of electrification of ur- 
Fig. 1 Population without access to electricity by in Sub-Saharan. (World Energy Outlook 2014 (International Energy Agency (IEA) 2014a))

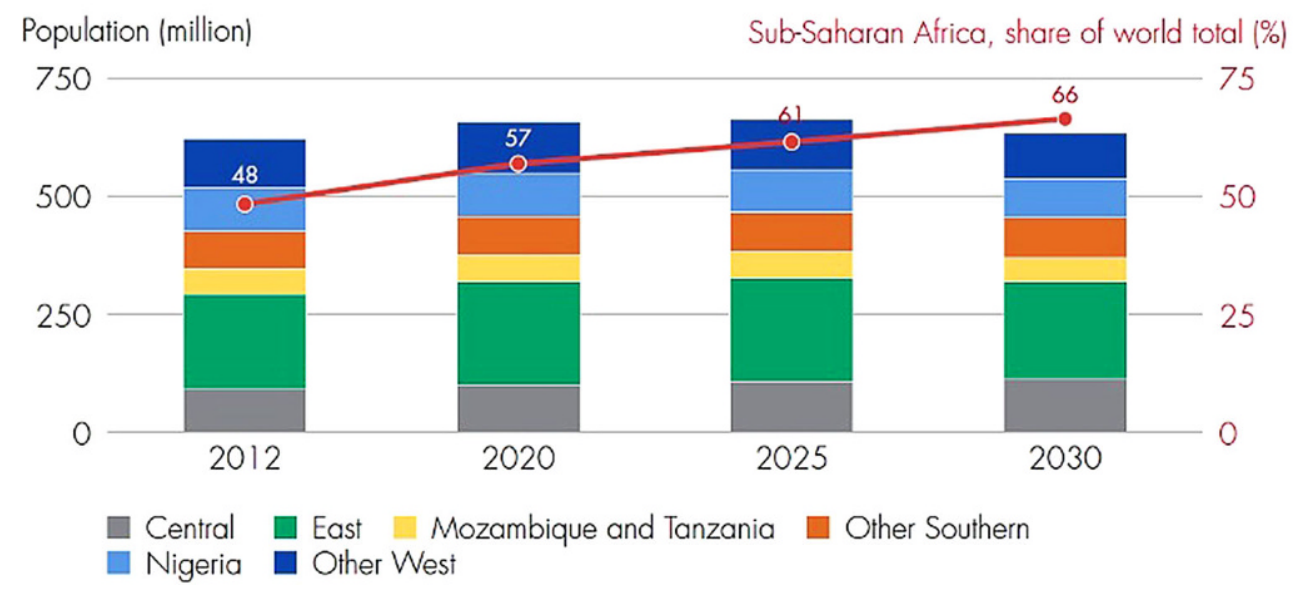

Fig. 2 Access to electricity \% of population with Tanzania highlighted (red) (Worldbank 2018) ban habitats and rural areas. While the urban population has coverage of $65.3 \%$, only $16.9 \%$ of rural population is supplied with electricity (World Energy Outlook 2018, International Energy Agency [IEA 2018b]). Therefore, people are still dependent on traditional material, usually wood, charcoal dung, etc. for cooking and heating.

As of June 2016, Tanzania has a total capacity of grid connected $1474 \mathrm{MW}$ and $54 \mathrm{MW}$ off-grid. The different sources are hydropower (38\%), natural-gasfired power plants (49\%) and liquid-fuel power plants (12\%). Imports from countries around (Uganda, Zambia, Kenya) are less than $1 \%$ of Tanzania's power (Eberhard et al. 2018).
In this article, the application of a second life LIB reuse, in connection with a PV system, is outlined as a minigrid solution. We describe electrification of an island in Lake Victoria in Tanzania (Fig. 3) which due to its size and small population (150 people) was not intended by local energy suppliers for the connection to the national power grid. However, as part of the here described cooperation project, regional infrastructure should be provided on the island by applying a customized off-grid solution. Primary focus of this project was the supply of the key infrastructure. These include the local school, where in addition to the lighting, computers should be used for education. 
Fig. 3 Map of Lake Victoria region in Tanzania with point on island Kibumba where the off-grid solution was deployed (Google Earth: Kibumba Island, Tanzania 2019)

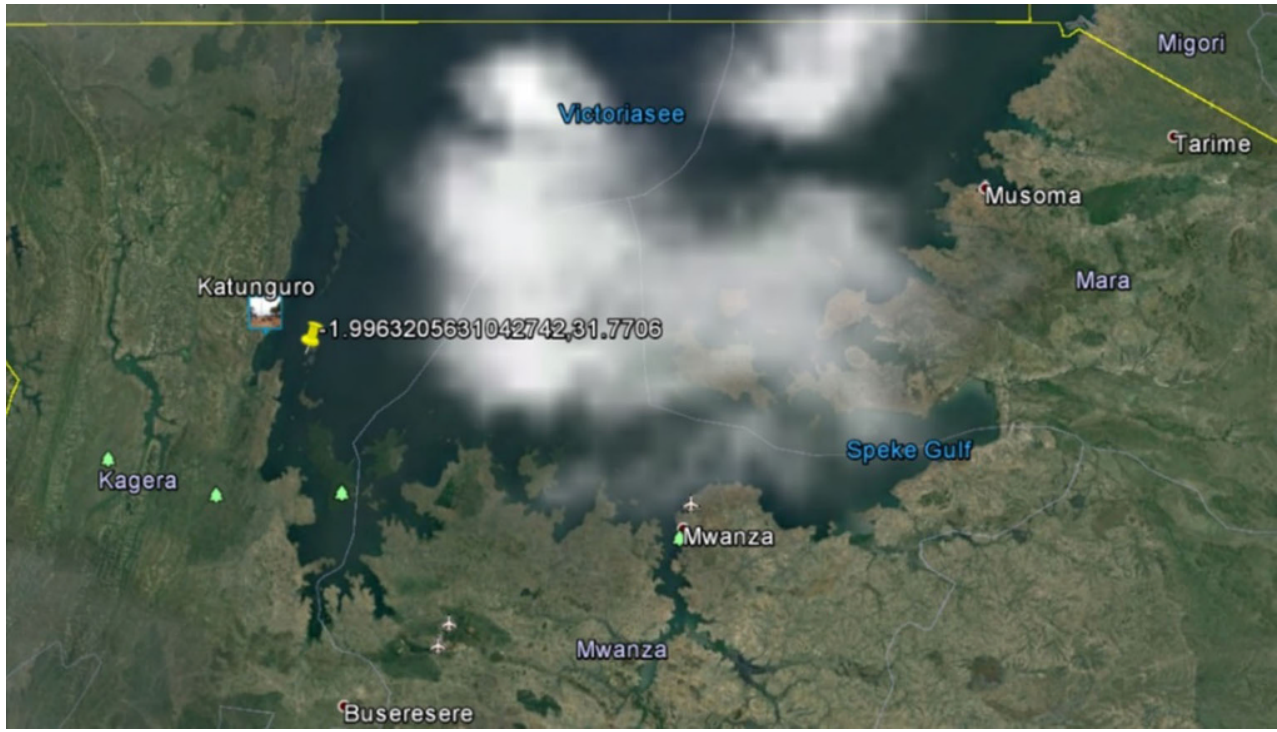

The hospital, to light up treatment rooms, cool medicines and to use electrical medical equipment. Such as the local fishery, which hopes that cooling possibilities results in economic potential.

\subsection{Hypothesis and Aims}

It is to be to shown that LIBs, following their first use in electric vehicles, are well suited for a second life application in mini-grid systems. In combination with photovoltaic plants, the opportunity of decentralized power supply will be demonstrated in order to support remote or undersupplied areas with modular and easily available power systems in their development. This should increase the degree of electrification in rural areas and make a valuable contribution to the socio-economic development. The advantages of second life LIBs compared to conventional fossil-fueled systems is to be shown. In addition, this should represent a further scenario that enables the possible reuse of endof-life electric vehicle batteries, which have so far mainly been used in energy storage systems.

\subsection{Methods}

The socio-economic development and consideration of corresponding factors is a central element of this article. The discussion is qualitatively conducted on the basis of literature such as (Elf et al. 2017), (Peters und Sievert 2016), (Ohler und Fetters 2014), (IEA-International Energy Agency), (Apergis und Payne 2010).

\section{Lithium-ion Batteries}

\subsection{Why to Use Lithium-ion Batteries?}

As a platform technology, LIBs represent the state of the art for electromobile applications. In 2015, the demand for such battery cells was already $15-30 \mathrm{GWh}$. Based on current estimates, demand could increase to as much as 300-1000 GWh by 2030 (Thielmann et al. 2015). This will undoubtedly lead to a reduction in cell costs and an additionally increased demand. It is estimated that reducing costs by a factor of two will increase global demand by a factor of 5-10 compared to 2015. Although lithiumsulfur or lithium-solid batteries provide alternative future technologies that have the potential to replace conventional LIBs with nickel manganese cobalt oxide, lithium nickel cobalt aluminum oxide or lithium iron phosphate cathodes and graphite anodes, there is still a great need for research and development to generate higher energy densities (Scrosati und Garche 2010). It will probably not be possible to meet the required demands with these technologies before 2030 . This means that LIBs can be called a reference technology for the upcoming years.

Although other battery types such as nickel metal hydride batteries (non-lithium-ion) continue to be used in hybrid electric vehicles, it can be assumed that these battery types will be successively replaced by LIBs, especially in electromobility (Thielmann et al. 2015).

\subsection{Second Life of Lithium-ion Batteries}

In many industries, more and more batteries based on lithium-ion technology are used. In terms of ecological and economical reasons it is desirable to re-use batteries that 


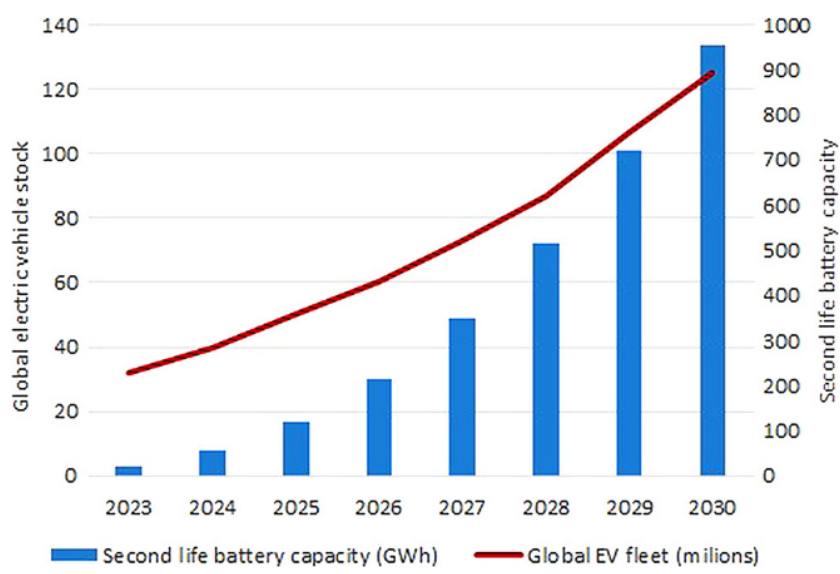

Fig. 4 Expected global second life battery capacity and electric vehicle stock based on - (Global EV Outlook 2018a, New Policies Scenario International Energy Agency [IEA]) and Bangemann, Battery Production today and tomorrow (Berylls Strategy Advisors 2018)

cannot be used in their primary application field any longer (Ahmadi et al. 2017). An industry in which more and more large-volume batteries are used is automotive industry.

The transition of this industry from fossil based fuels to low-emission and/or emission-free mobility and thereby sustainable solutions is directly linked. However, this change can only succeed if ranges, charging times, safety and comfort of electric vehicles can compete with conventional vehicles. The development of efficient LIBs is the crucial factor. Since its launch in the early 1990s, primarily used in consumer electronics, transmission to largeformat solutions are currently underway to meet the upcoming requirements of electromobility (Thielmann et al. 2015). However, the vision of widespread electromobility displays a major challenge, as the rising sales volume of electric vehicles will undoubtedly lead to an increase in spent batteries. In Fig. 4 an expected worldwide second life battery capacity of approximately $953 \mathrm{GWh}$ by the year 2030 (Berylls Strategy Advisors 2018) by an estimated global electric car stock of 125 millions is visualized, excluding two- and three-wheelers (IEA-International Energy Agency).

According to this estimated development there is a remarkable demand such as potential for second life concepts for used LIBs. Depending on the manufacturer and the application, their replacement is carried out already at a residual capacity between 70-80\% (Podias 2018). In view of still useful performance of these batteries, re-use for less demanding applications is indispensable for economic but especially ecological aspects. Premature recycling contradicts the current societal considerations of finding ecologically sustainable solutions. Fig. 5. illustrates this life cycle of the first use and a possible second life of LIB from electromobility.

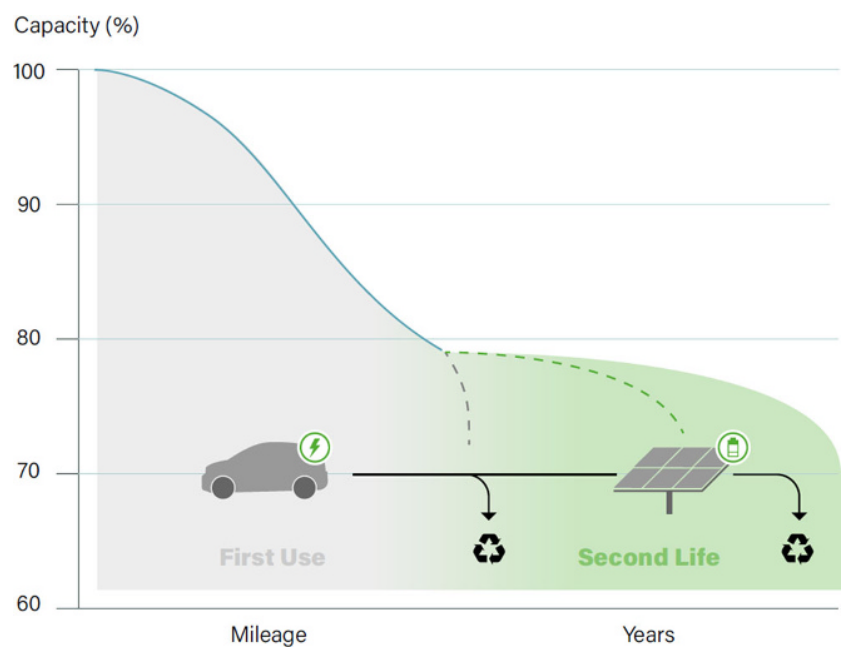

Fig. 5 Lifecycle of EV-Battery adapted by Saslab Final Report 2018

Such an application may be, the use as a power storage in an energy storage system (Zhang et al. 2018). As a part of Germany's energy transition renewable energy sources are increasingly being used. One of the major challenges in this context is to offset the volatility of energy availability. Because of the dependence on different weather conditions, wind power plants, solar plants and hydroelectric power plants seldom keep the exact energy demand constant. In general, either more or less power is produced as required, which inevitably leads to mains fluctuations. Consequently, energy storage is necessary to ensure network stability. Battery storage provides an opportunity to compensate for voltage fluctuations by taking over capacity or to provide additional supply (Fuchs et al. 2012). However, one of the major challenges is undoubtedly the economic efficiency of using second life batteries compared to newly manufactured cells. As already described in Fig. 4 electric mobility will increase significantly in the coming years. This will lead to a significant increase in the availability of traction batteries. In Table 1. a market scenario is shown, which developments are to be expected with regard to the increasing availability of second life batteries. In particular, the cost advantages of used compared to new batteries are an interesting economic approach.

Although it is currently difficult to predict how the benefits of secondary use will in the future affect the cost structure of new batteries, the benefits to the environment are obvious. For example, the re-use of LIBs may result in fewer new batteries being produced, especially for battery solutions or applications outside electric mobility. (MartinezLaserna et al. 2018). 
Table 1 Battery market price scenario adapted by Martinez-Laserna et al. (2018)

\begin{tabular}{llll}
\hline Lithium-ion battery & & & \\
\hline New & Second life & Cost of refurbishment & Refurbished \\
250 USD/kWh & $51-131 \mathrm{USD} / \mathrm{kWh}$ & $32-49 \mathrm{USD} / \mathrm{kWh}$ & $83-180 \mathrm{USD} / \mathrm{kWh}$ \\
\hline
\end{tabular}

\subsection{Diesel Generator as Discontinued Model}

Diesel generators are typically the solution for off-grid electrification systems. Because of their low initial costs, they are a favorable option. However, looking more closely, it becomes clear that increased fuel costs and high maintenance costs, as well as transportation costs for moving bulky equipment to remote areas (Naudé et al. 2007), decrease initial cost advantages. Although modern generators work more efficiently, they still require between 0.28 and 0.41 of fuel per $\mathrm{kWh}$, depending on the performance (Szabó et al. 2011). Assuming the use of a very efficient diesel generator with an average consumption of 0.281 of diesel per $\mathrm{kWh}$, based on the average diesel price of USD 1.06 in Tanzania in 2018, this results in a value for the $\mathrm{kWh}$ produced by a diesel generator of USD 0.2968. In addition various scenarios show that diesel generators will perform worse if used for mini grid systems, in direct comparison with battery solutions in lifecycle costs, costs of energy and carbon dioxide emissions (Ogunjuyigbe et al. 2016). Steadily falling prices for photovoltaic modules, battery cells, system integration and installation contribute significantly to achieving competitive cost structures of fossil fuel methods for electricity generation (International Renewable Energy Agency (IRENA) 2017). In addition, to the economic considerations, pollution from carbon oxides emissions is a great disadvantage and contrary to the environmental as- pirations worldwide. In this context, emissions are defined as the emission of greenhouse gases, especially $\mathrm{CO}_{2}$, which are released during the combustion of carbonaceous materials, in this case diesel fuel. Depending on the type and efficiency of the generators and the quality of the fuel, average emissions can be in the range of $2.4-2.8 \mathrm{~kg} \mathrm{CO}_{2}$ per litre of diesel consumed (Waqas et al. 2018). In addition, even with modern generators, the noise level during operation cannot be neglected. This can have a direct effect on the quality of life and health of people in the immediate vicinity (Maschke und Fastl 2017).

In Fig. 6 the average diesel price per litre in Tanzania over the last 20 years is shown. In 1998, the average price of a litre of diesel was USD 0.57 per litre. In 2008, the cost more than doubled to USD 1.30 per litre and in 2018 it was again somewhat lower at USD 1.06 per litre. If these factors are applied to the scenario described in this article, the preference for a photovoltaic system instead of a diesel generator solution is obvious, especially in view of the volatile development of diesel prices. Fuel costs here have risen significantly, above all because the fuels have to be imported leading to dependency. Although measures are being taken by the government to counteract the fluctuations, these cannot stop the global trend (Chegere et al. 2013). If Tanzania were to primarily use diesel to generate electricity, generation costs would be relatively high and difficult to plan compared to PV systems (Moner-Girona
Fig. 6 Diesel Prices Tanzania USD/litre Data from: KNOEMA AND GLOBAL PETROL PRICES

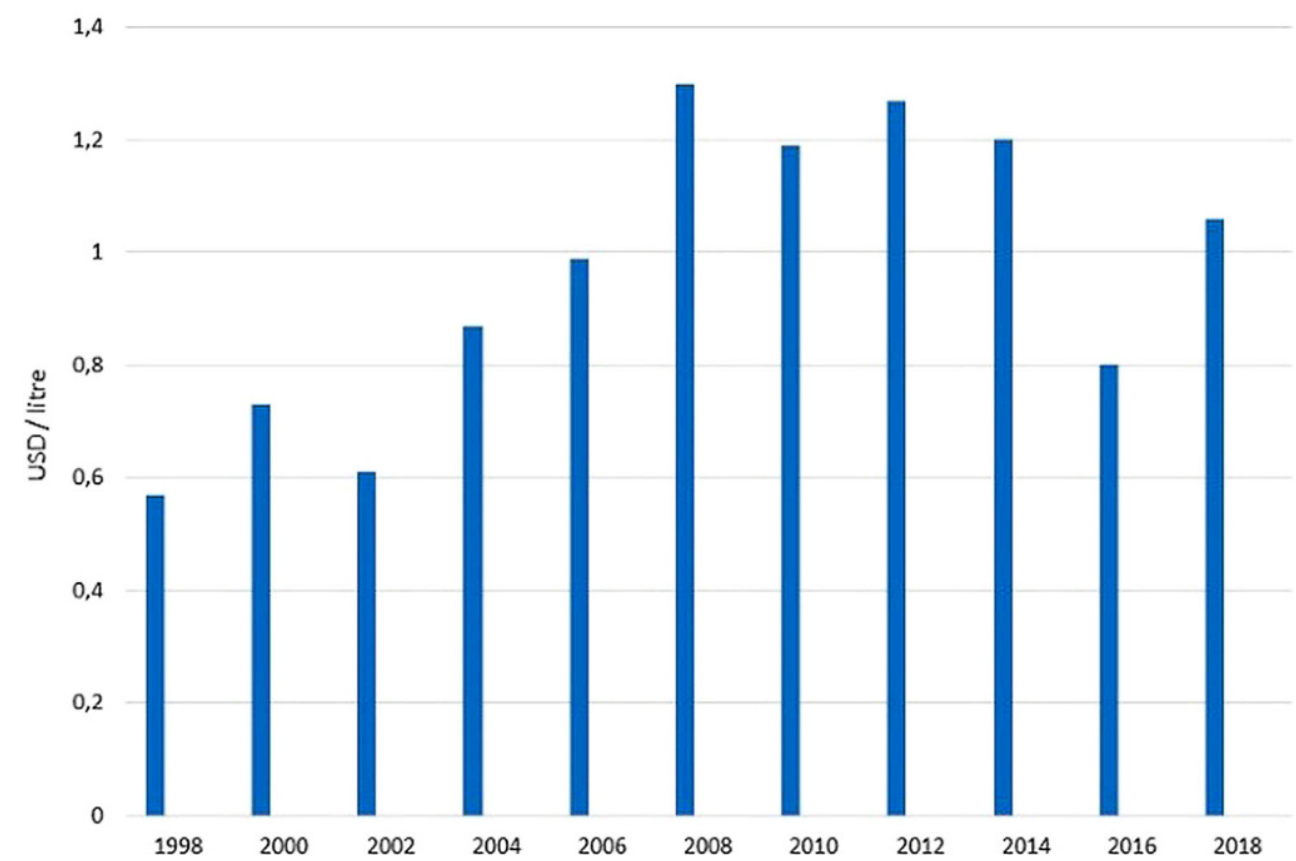



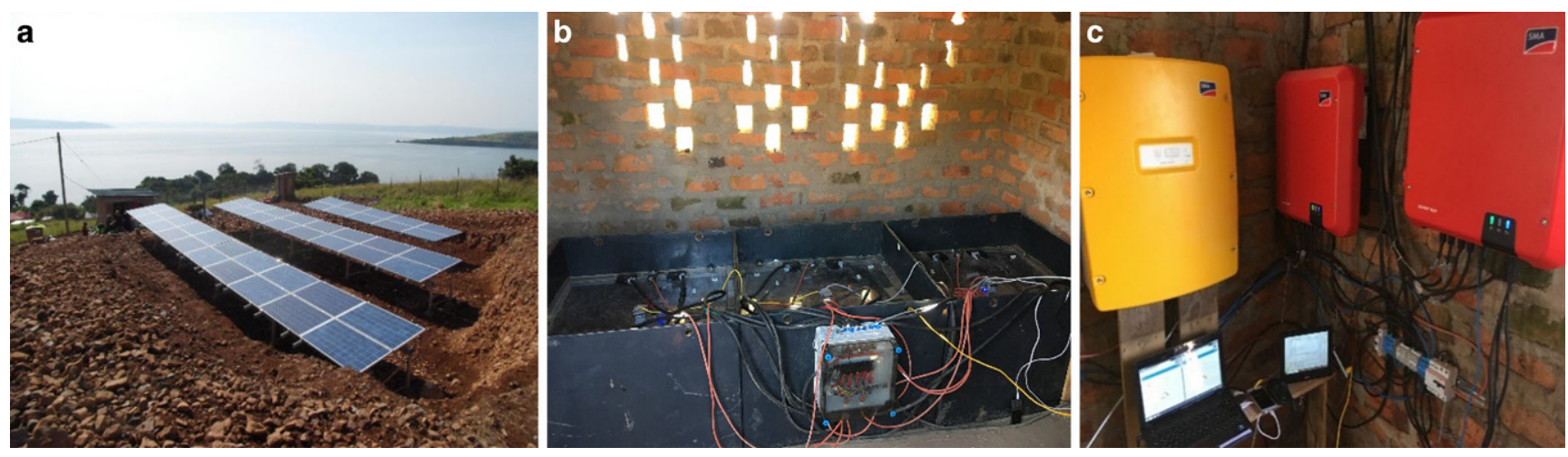

Fig. 7 Pictures Onsite from left to right: a, b, c

Fig. 8 Schematical Setup of the PV-Hybrid Mini Grid System

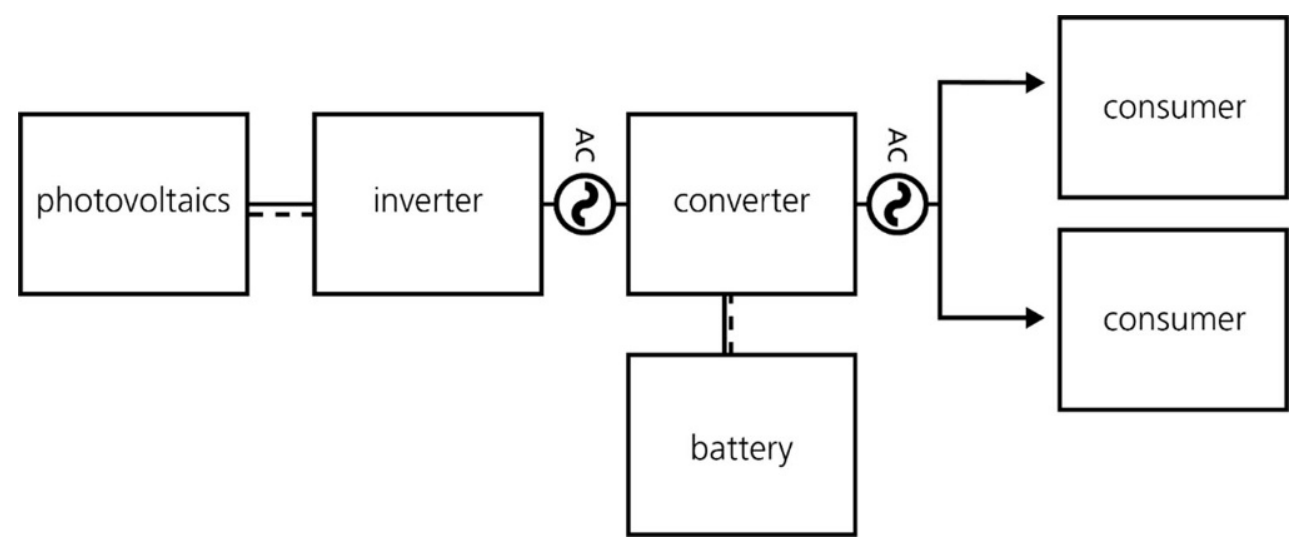

et al. 2016). In addition to the economic view, additional factors must be taken into account. The poor state of the infrastructure, the associated lack of guaranteed nationwide availability of fuel make it necessary to stockpile fuel for an uninterrupted supply of electricity. In addition to the hazardous storage of highly flammable liquids, the costs for their safe storage are particularly problematic (Abbasi et al. 2017).

\section{Case Description}

In this section, the situation on site, the equipment, points of technical feasibility and commissioning and an economic calculation are presented. Fig. 7 shows three pictures on site. On picture a the installed solar modules in front of the Viktoria Lake is shown. The battery system is visualized on picture b. On picture $\mathbf{c}$ inverter and converter can be seen.

\subsection{Description of Equipment}

An off-grid system is a power generation system that is not connected to a public power grid. These systems are often referred to as stand-alone or mini-grid systems or in combination with other components such as batteries, as hybrid systems (Sandeep Lal and Atul Raturi 2012). The system visualized in Fig. 8 uses photovoltaics to generate direct current when exposed to the sun. With a PV-inverter, the energy generated is converted into alternating current and fed into the alternating current grid.

This consists of a further inverter which regulates the voltage, frequency and energy flow of the grid. If there is a surplus of energy, the LIB integrated will be charged. Then, it can provide energy at night or in the event of supply shortage. The detailed list of the applied components, the units and specifications of the PV-hybrid mini grid system is shown in Table 2 .

\subsection{Technical Feasibility}

The geographical location and climatic conditions in Tanzania, especially the average annual hours of sunshine, provide an excellent environment for using solar energy. As one of the countries located on the Sunbelt (areas south of the 37th parallel), Tanzania has a very high solar radiation which according to PVGIS Database ranges from 2000 to $2500 \mathrm{kWh} / \mathrm{m}^{2}$ (European Commission Joint Research Centre 2019). Several examples in Tanzania show that it is 
Table 2 Applied components for the PV-Hybrid Mini Grid System

\begin{tabular}{lll}
\hline Components & Units & Specifications \\
\hline Battery system & Li-Ion, 2nd life, 72 cells & $85 \mathrm{kWh}, 44 \mathrm{~V}$ \\
Photovoltaics & $46 \times$ Polycrystalline & $230 \mathrm{Wp}, 30.27 \mathrm{~V}$, \\
& module & $7.06 \mathrm{~A}$ \\
Inverter & $1 \times$ Off-grid inverter & $<8 \mathrm{~kW}$ \\
& $2 \times \mathrm{PV}$ inverters & $<5.25 \mathrm{~kW} /<600 \mathrm{~V}$ \\
\hline
\end{tabular}

Table 3 PV-hybrid mini grid system calculation

\begin{tabular}{ll}
\hline PV-hybrid mini grid system & EUR \\
\hline $46 \times$ Photovoltaics & 3500 \\
$1 \times$ Off-grid inverter & 2750 \\
$2 \times$ PV inverter & 2200 \\
$1 \times$ Second life battery $(85 \mathrm{kWh})$ & 7000 \\
Small parts and cables & 1500 \\
Logistics & 3825 \\
Personnel costs (preparation, installation, measurement) & 15,000 \\
Sum total & 35,775 \\
\hline
\end{tabular}

possible to supply public buildings such as schools and hospitals etc. with solar powered energy solutions (Vogler et al. 2016). In addition, solar-powered street lighting is already being used. Further projects in economic sectors such as telecommunications and mining but also increasingly in agriculture to operate water pumps point up the basic technical feasibility of such solar-powered mini-grid systems (Moner-Girona et al. 2018).

\subsection{Commissioning}

\subsubsection{Logistics}

The technical equipment included components with a total weight of three tons: The weight of the battery cells is $670 \mathrm{~kg}$ and in total $1350 \mathrm{~kg}$ for the entire battery system. The solar modules including foundation weigh $900 \mathrm{~kg}$, fixing material and power cables $400 \mathrm{~kg}$, tools $200 \mathrm{~kg}$, and packaging $200 \mathrm{~kg}$, respectively. In Germany, the transport of used battery cells is generally regarded as hazardous goods and requires a certificate from the Federal Institute for Materials Research and Testing (BAM). In addition, appropriate export and accompanying documents are required for the ten-week transport via road and sea to Tanzania. The formalities of the four-week import process were handled by a local service provider. Due to the local infrastructure in Tanzania, the transported goods had to be reloaded several times. First on smaller trucks later on boats to reach Kibumba Island. The system had to be completely disassembled as the local boats were not designed for this kind of transport.

\subsubsection{Preparatory Measures}

The installation of the photovoltaic modules and the battery system required preparatory work in advance, for which the local project partner was responsible. A small hut with a floor area of $3 \times 2 \mathrm{~m}^{2}$ was built for the battery system. The concrete columns for the PV modules as well as the earthworks for the cable infrastructure were also prepared in advance. Hence the installation could immediately start with the arrival of the equipment.

\subsubsection{Operating}

Due to the preparatory work already carried out by the project partner, the complete mini-grid system could be set up in around six days with the support of local workers. This included the installation and correct alignment of the solar panels as well as the construction and connection of the battery system. In addition, cables, switches and sockets were laid in the hospital and the school. This was followed by a two-day successful test phase of the system. During the test measurements, an average feed-in energy of $42.31 \mathrm{kWh}$ per day was provided. This enabled the determined demand to be met on the one hand and on the other hand the plant offers enough potential for the further development of Kibumba.

\subsection{Economic Calculation}

The applied components for PV hybrid mini grid system are listed in Table 3 at the average market price. The valuation of the second life battery based on Table 1 . Due to the remaining capacity of the battery used here, the $\mathrm{kWh}$ was valued at $€ 88$.

The DST230P6-60S solar modules come from DS Technology at $€ 76$ each. The SMA Sunny Island $8.0 \mathrm{H}$ off-grid inverter is valued at $€ 2800$ and the two SMA Sunny Boy 5.0 PV inverters at $€ 1100$ each.

The calculations of representative costs of electricity and amortisation times for such systems have large numbers of different influencing variables such as location, installation and maintenance costs or electricity consumption, respectively. Due to this, especially the determination of the rate of depreciation has a considerable uncertainty. The depreciation rate depends on the depreciation method. The depreciation method has been adapted to the exemplary presentation in the following depreciation calculation, whereby the straight-line method is most suitable. This method is based on the assumption that an asset is subjected to uniformly high stress over the period of time (Bosch 2010). Due to the prototype character of the system, it is suitable for an exemplary consideration in comparison to degressive and progressive depreciation methods. 
The investment for the technical components is initially high. However, with an expected service life of 15 years, the assembly described here can pay for itself in the 4th year onwards as shown in calculation III.

The local provider Jumeme Ltd. specialises in the decentralised power supply of remote locations with PV-hybrid mini grid systems and acted as a local partner in the implementation of the scenario described here. In preparation, an evaluation of electricity demand, electricity costs and system size has been carried out for technical implementation. A daily approximate requirement of $18.75 \mathrm{kWh}$ for the location and a system dimension for an energy supply of $3125 \mathrm{~kW}$ were determined. Jumeme Ltd. usually offers three different tariffs and calculated the following costs for the use on Kibumba, measured by the expected consumption values. For public institutions and private households $1.35 € / \mathrm{kWh}$, for commercial customers (small shops and businesses) $0.96 € / \mathrm{kWh}$ and for manufacturing facilities (big plants) $0.29 € / \mathrm{kWh}$ plus a weekly provision fee of $3.83 €$. (Nedjalkov et al. 2019).

On basis of the estimated daily energy requirement on Kibumba Island of $18.75 \mathrm{kWh}$, the electricity costs for energy supply by Jumeme Ltd. would be $€ 8356.23$ per year, as shown in the following calculations I and II.

Due to different customer groups, the daily requirement is divided accordingly $9.75 \mathrm{kWh}$ at $1.35 € / \mathrm{kWh}$ for school, hospital, private househoulds (I.) and $9.00 \mathrm{kWh}$ at $0.96 € / \mathrm{kWh}$ for the fishery (II.).

\section{Electricity Cost for School, Hospital, Private Housholds:}

Annual requirement in $\mathrm{kWh}$

$$
\begin{aligned}
& =\text { daily requirement in } \mathrm{kWh} \times 365 \text { days } \\
& =9.75 \times 365 \\
& =3558.75
\end{aligned}
$$

Annual costs in EUR

$$
\begin{aligned}
& =\text { annual requirement in } \mathrm{kWh} \times \text { cost per } \mathrm{kWh} \text { in EUR } \\
& =3558.75 \times 1.35 \\
& =4804.31
\end{aligned}
$$

Annual connection fee in EUR

$$
\begin{aligned}
& =\text { weekly connection fee in EUR } \times 52 \text { weeks } \\
& =3.83 \times 52 \\
& =199.16
\end{aligned}
$$

Total electricity costs in EUR

$=$ annual costs in EUR + annual connection fee in EUR

$=4804.31+199.16$

$=\underline{\underline{5003.47}}$

\section{Electricity Cost for Fishery:}

Annual requirement in $\mathrm{kWh}$

$$
\begin{aligned}
& =\text { daily requirement in } \mathrm{kWh} \times 365 \text { days } \\
& =9.00 \times 365 \\
& =3285.00
\end{aligned}
$$

Annual costs in EUR

$$
\begin{aligned}
& =\text { annual requirement in } \mathrm{kWh} \times \text { cost per } \mathrm{kWh} \text { in EUR } \\
& =3285 \times 0.96 \\
& =3153.60
\end{aligned}
$$

Annual connection fee in EUR

$=$ weekly connection fee in EUR $\times 52$ weeks

$=3.83 \times 52$

$=199.16$

Total electricity costs in EUR

$=$ annual costs in EUR + annual connection fee in EUR

$=3153.60+199.16$

$=\underline{3352.76}$

As already described under 3.3, an average energy of $42.31 \mathrm{kWh}$ could be provided daily with the system, which corresponds to an annual production of $15,443.16 \mathrm{kWh}$.

This electricity yield serves the basis for the following calculation III of the amortisation with an assumed useful life of 15 years assuming annual maintenance costs of $€ 1000$ :

\section{Amortisation of PV-hybrid Mini Grid System:}

Annual depreciation in EUR

$$
\begin{aligned}
& =\frac{\text { Acquisition costs in EUR }}{\text { Useful life in years }} \\
& =\frac{35,775}{15}=2385
\end{aligned}
$$

Price per $\mathrm{kWh}$

$$
\begin{aligned}
& =\frac{\text { Annual costs }+ \text { depriciation in EUR }}{\text { annual production in } \mathrm{kWh}} \\
& =\frac{(2385+1000)}{15,443.16}=0.219
\end{aligned}
$$

Amortisation period

$$
\begin{aligned}
& =\frac{\text { Acquisition costs in EUR }}{\text { Annual electricity costs in EUR }} \\
& =\frac{35,775}{8356.23}=\underline{\underline{4.28}}
\end{aligned}
$$

Values such as the possible purchase price of a property, insurance and disposal costs are not taken into account in the calculation. 


\subsection{Ecological Evaluation}

A major challenge is to achieve a reduction of greenhouse gases with future approaches to energy supply. The generation of energy by burning fossil fuels produces high emissions of pollutants for the environment. However, other forms of energy production such as solar technology or batteries are not excluded from this consideration. Although there are almost no emissions during operation, emissions for the production of solar modules and batteries must be included in the assessment as life cycle emissions. These depend both on the type of production facilities and the materials used and can vary from country to country (Fthenakis et al. 2008). Due to these many influencing variables, a direct comparison of the components is extremely difficult. For this reason, the respective emission levels are outlined below using existing literature. For the following values also the term carbon dioxide equivalent $\left(\mathrm{CO}_{2 \mathrm{eq}}\right)$ is used, which partially reflects the emission of $\mathrm{CO} 2$ during the entire life cycle of a product (Wiedmann und Minx 2007). As indicated in Sect. 2.3, average emissions from conventional diesel generators are in the range of $2.4-2.8 \mathrm{~kg} \mathrm{CO}_{2}$ per litre of diesel consumed (Waqas et al. 2018). For the annual energy production of $15,443.16 \mathrm{kWh}$, which could be achieved with the off-grid hybrid system described in this article, an average $\mathrm{CO}_{2}$ emission of $2.4 \mathrm{~kg}$ per litre of diesel would produce a total load of $10,381.96 \mathrm{~kg} \mathrm{CO}_{2}$ per year. Assuming the operation of an efficient generator that can produce $1 \mathrm{kWh}$ with 0.281 of diesel. In comparison, the life cycle emissions for crystalline silicon pv modules are between 30-45 $\mathrm{g} \mathrm{CO}_{2 \mathrm{eq}} / \mathrm{kWh}$ (Alsema und Wild 2005). Depending on factors such as battery design, inventory data, modelling and manufacturing the production of lithiumion batteries currently generates emissions of $150-200 \mathrm{~kg}$ $\mathrm{CO}_{2 \mathrm{eq}} / \mathrm{kWh}$ (Romare und Dahllöf 2017). Undoubtedly the battery is the largest contributor to $\mathrm{CO}_{2 \mathrm{eq}}$ emissions. It is all the more important that batteries remain in use as long as possible and are not recycled prematurely. So the reuse of used batteries for a second life scenario, as described in this article, has an essential environmental benefit as the emissions from the manufacturing process are split between first and second use before the recycling process is initiated, thus also improving the environmental performance could improve in the range of potential $7-40 \%$, of the components used (Cusenza et al. 2019).

\subsection{Socio-economic Impact}

Undoubtedly, the access to electricity is highly important for improving subsistence of people. It is considered undisputed that linking socio-economic development with affordable clean and sustainable energy solutions, health and livelihoods significantly improve. Reliable supply of elec- tricity allows many opportunities, especially if people do not depend on daylight only. The associated advantages and opportunities are visualised exemplary in Table 4 using three basic indicators: health, education and business. Improving the health of people and their living environment by apply of electricity are essential benefits. On the basis of the air pollution, oil lamps, kerosene and solid fuels for cooking or heating are major sources of harming household members (Elf et al. 2017). These inefficient and expensive energy sources are the main cause for health risk, premature mortality, diseases like childhood pneumonia, heart disease, cancers, and chronic respiratory. Electricity provides alternative healthful options for light sources, clean and affordable cooking solutions, and many daily needs for example cooling food (International Energy Agency 2014b). The use of electrically operated medical devices, but above all, the ability to cool medications and thereby extend their durability, has a direct impact on the quality of local people lifes (Peters und Sievert 2016). In addition, education is supported if there is a continuous power supply in the school. This means that teaching and learning can take place independently of the daylight and new media such as internet and computer can be used.

In addition, possible business models are independent of the time of day, which leads to an increased number of yield opportunities by using new electric machines and, for example, new media can be used. With regard to the macroeconomic, situation there is a causal relationship between electricity, renewable energy sources in particular, and economic growth (Ohler und Fetters 2014).

Even though, the focus of this project was initially on the key infrastructure such as hospital and school, it is clear that conventional households will also benefit from this project. The electrification of the school enables learning events to be carried out independently of the time of the day and the lighting conditions. The operation of computers can significantly support education. This creates an additional potential for further education as well as an improvement of living conditions. The hospital can provide medical care during the whole day.

The local fishery can store goods longer by the operation of cooling systems for further transport to surrounding trading places. This improves the hygienic conditions of local food storage as well as the basic supply of fish to people. It is not further necessary to sell all the fish on the same day. Thus could compensating fluctuations in fishing yields. In addition, there is potential for growth in this sector, which can create jobs with positive effects on the economic development in this region. 
Table 4 Sozio-economic indicators and impact

\begin{tabular}{lll}
\hline Indicator & Scope & Impact \\
\hline Health & Air pollution household & No fossil fuels for light and cooking \\
& Water supply & Water pumps operations \\
& Nutrition & Cooling of food \\
& Medical treatment & Cooling of medicines \\
& & Hospital operations \\
Education & Learning periods & Daytime independent teaching and learning \\
& Learning aids & Application of new media (computer, internet) \\
Business & Range & Daytime independent services \\
& & Electric machines operations \\
& & New business models (installation maintenance) \\
\hline
\end{tabular}

\section{Discussion}

High energy consumption is often associated with the state of development of a country (Apergis und Payne 2010). While electricity is not an universal indicator of how to improve living conditions, the impact on a better quality of life is indisputable. Looking at the relationship between energy consumption and gross domestic product (GDP) in Fig. 9, it can be seen that countries with high electricity consumption also have a high GDP. While discussion suggests that the human development index (HDI) is better suited for evaluation of the state of development than energy consumption, there is a close correlation between energy consumption and a country's level of development. In addition, both perspectives make clear that the countries with the highest energy consumption belong to the best developed. This relationship can also be established for Tanzania and for the scenario described in this article.: the country ranks 154th out of 189 countries in the Human Development Index (HDI) (UNDP 2017). Nevertheless, it is important to include both approaches in the evaluation. Consequently, an improvement in the socio-economic living conditions on site can only succeed if the necessary electricity is provided. However, the exclusively qualitative discussion of the socio-economic aspects, especially the effects on health, must be validated for this concrete case study by future quantitative surveys. This should be implemented, for example, by means of a long-term study within the framework of further research.

The aim of the use case described in this article was to outline a possible reuse scenario, in combination with a socio-economic approach, for the expected amount of available LIBs due to increasing electromobility, which continues to be used for environmental and economic reasons due to its residual capacity of $70-80 \%$ to avoid prematurely recycling.

In addition to the technical feasibility of providing electricity in a remote area of Tanzania described in this article, the assessment of a possible entry into a niche market for mini grid systems is currently difficult to assess. At the moment many parameters make an economic implementation difficult. It should be noted in particular that every transport of a LIB is always considered transport of dangerous goods, regardless of whether the battery has damage or not (Korthauer 2018). Requirements make the transport complex and expensive. In certain circumstances transport as airfreight is not possible which requires to choose a lengthy sea route, as in the project described in this article. As a result, shipping of equipment described under 3.1., needed five weeks, also due to the poor infrastructure in Tanzania. The administrative expenses of importing goods to Tanzania is also very high as the import of goods requires a certificate of conformity $(\mathrm{CoC})$. This must be prepared in advance in the exporting country by commissioned audit firms such as Bureau Veritas and the company SGS as part of the pre-export verification of conformity to standards program (PVoC) (TBS 2017). Since EV batteries differ in specifications, depending on model series and manufacturer, in particular with regard to the battery management systems (BMS) (Hannan et al. 2017), standardized testing or evaluation is currently still complex and difficult. In addition, the profitability of future projects appears uncertain due to high import duties of $25 \%$ for lithium batteries (East African Community 2017) (HS code 8507.60.00).

Although, the certificates and import tariffs are designed to protect national markets and industries (Mutuku and Mbithi 2017), it is advisable that authorities support the import of such systems in view of Tanzania's electrification efforts. Supporting measures could include that import of systems described in this article could be favored such as relief supplies, which are excluded from the PVoC and exempted from import duties (TBS 2017).

The use of LIBs offers significant advantages over commonly used diesel generators.

As described under 2.3., the initial costs for such generators are comparatively low, but operating and maintenance costs very high. Especially with regard to the very volatile fuel prices as shown in Fig. 6 and the related difficulties of cost-intensive and safe fuel storage. The respective calculated costs for the average production of one $\mathrm{kWh}$ for the diesel generator of USD $0.2968 / \mathrm{kWh}$, as indicated in Sect. 2.3 and the USD $0.250 / \mathrm{kWh}$ (exchange rate Febru- 
Fig. 9 Relationship between GDP and Electricity consumption (IHS Economics; International Energy Statistics, U.S. Energy Information Administration (2013))

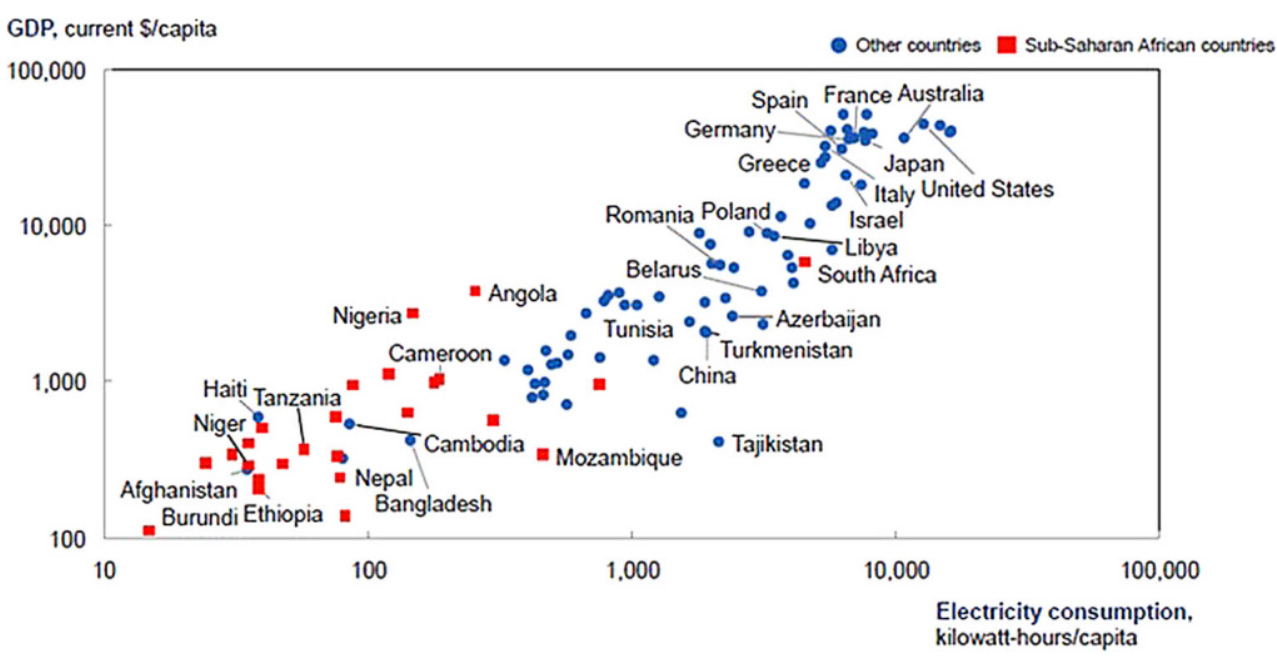

ary 2019) listed in Sect. 3.4, calculation III for the offgrid system used on Kibumba, show the advantages of the project from an economic perspective. In addition, health aspects such as air pollution from the burning of fossil fuels and noise during operation are significant disadvantages. Accordingly, LIB represent a very good ecological and economic alternative for the scenarios described in this article. The use of second life LIB offers an additional economic advantage.

As shown in Table 1, refurbished LIB has a cost advantage of $28 \%$ over new batteries.

However, a major challenge is the development of an end-of-life strategy of used batteries. Optimized recycling of LIBs is still not fully develop. Because batteries for electric cars are designed primarily for use in vehicles and not optimized for reusability. Suitable processes are still under development or very complex, and many preparatory work is needed before actual extraction of raw materials (Engel and Macht 2016). About $60-70 \%$ of a battery pack are battery cells or modules, the rest consist of connectors, cooling elements, substrates and the housing. These are metals and plastics that can be easily extracted using established recycling processes (Bulach et al. 2018). It is therefore crucial to accompany the widespread use of systems described in this paper with the development of an end-of-life strategy and to highlight the ecological and economic potential of a recycling. The implementation of such projects should not be understood as a shift in the waste problem after the end of the life of a battery, but as an opportunity to cover the resource requirements for electric mobility with recovered raw materials and thus to establish a new branch of industry. For this, however, local structures must be created to avoid that the corresponding components are not properly recycled, for example by improper burning. This would again create health risks (Feldt 2017). Although, Tanzania has a large mineral resources, it does not have the raw ma- terials that are required for electro mobility, such as lithium (Tanzania High Commission 2019). In addition, the benefits introduction to all involved are obvious because due to the fast and flexible supply with electricity rural areas develop socio-economically positively. Second-life batteries also offer a price advantage compared to new batteries as visualized in Table 1 which means that energy can be supplied more inexpensive. The competitive target for favouring such used batteries should be around $€ 80 / \mathrm{kWh}$ (Jiao 2018). For research this second-life operation of batteries provides valuable data on the long-lasting behavior which may result in improvements for the reliability of primary cells. This may also have a positive impact on the attractiveness of electric mobility.

\section{Conclusion}

In this article, we have outlined a possible reuse scenario for electronic vehicle second life LIBs.

In the context of further increasing electromobility and thereby the undisputed perspective return of batteries. In addition to the partially established application possibilities in energy storage systems, we have shown that in combination with the described equipment there is an excellent opportunity to set up off-grid solar powered systems. The advantages of using a battery, especially the LIB, compared to a conventional diesel generator solution became particularly apparent when considering the socioeconomic indicator health. In addition, the direct cost comparison of the average generation for one $\mathrm{kWh}$ of both systems indicates significantly higher costs for the diesel generator solution. The proven use of the described system on an island in Lake Victoria in Tanzania underlines the potential to provide flexible and quick electricity to rural regions without stationary power supply. 
The conditions are favourable due to international efforts to electrify Africa. As part of Phase II of the AREI project, additional capacities of 300 gigawatts of renewable energies are to be created by 2030. In addition, Africa is a priority continent for Bundeministeriums für wirtschaftliche Zusammenarbeit und Entwicklung (BMZ).

The focus is on promoting decentralised small systems and networks that generate energy without fossil fuels.

Investments are also to be stepped up in measures in which municipalities, with the direct involvement of local people and SMEs, implement sustainable energy generation and supply. The BMZ specifically proposes the creation of municipal utilities and energy cooperatives, for example, in order to create the legal and political conditions for decentralised energy supply (Bundesministerium für -wirtschaftliche -Zusammenarbeit und Entwicklung (BMZ) 2017a). In this context, a focused promotion of the system described in this article seems possible and, above all, more sensible than the development financing of protracted and cost-intensive large-scale projects. Specifically, direct support may include the subsidisation of batteries or entire hybrid systems, including installation and commissioning costs. Even if administrative hurdles such as high import tariffs $(25 \%)$ on LIBs as well as a high bureaucracy in the preparation of $\mathrm{PVoC}$ make import more difficult and used LIBs as dangerous goods can only be transported under certain conditions, against the background that despite international efforts and development programs, more than 600 million people in the sub-Saharan region still have no access to electricity and further electrification is slow to progress, systems such as those described here can make a valuable contribution to supplying more people with electricity.

In addition to basic electricity supply, a number of positive effects, for example as shown in Table 4, could support the combination of socio-economic development with clean and sustainable energy solutions and significantly improve living conditions in the regions concerned. Medical care and education in particular can take place regardless of the time of day and sunlight and can be made more comprehensive through the use of technical equipment. Furthermore, opportunities arise for the respective local economy with new business models to generate additional income. This case study is basically intended to verify the feasibility and investigate the durability of battery systems in secondary use. If the system is to be launched on the market as a product, the major challenge is to find a solution for handling the system after its use in order to avoid negative effects, especially on the health of local people due to improper handling. This should be considered and validated in further research.

Funding Open Access funding provided by Projekt DEAL.
Open Access This article is licensed under a Creative Commons Attribution 4.0 International License, which permits use, sharing, adaptation, distribution and reproduction in any medium or format, as long as you give appropriate credit to the original author(s) and the source, provide a link to the Creative Commons licence, and indicate if changes were made. The images or other third party material in this article are included in the article's Creative Commons licence, unless indicated otherwise in a credit line to the material. If material is not included in the article's Creative Commons licence and your intended use is not permitted by statutory regulation or exceeds the permitted use, you will need to obtain permission directly from the copyright holder. To view a copy of this licence, visit http://creativecommons.org/licenses/by/4. $0 \%$

\section{References}

Abbasi et al (2017) An assessment of the prevailing codes/standards and models for determining safe spacing between two or more hazardous storage tanks

Ahmadi L, Young SB, Fowler M, Fraser RA, Achachlouei MA (2017) A cascaded life cycle: reuse of electric vehicle lithium-ion battery packs in energy storage systems. Int $\mathrm{J}$ Life Cycle Assess 22(1):111-124. https://doi.org/10.1007/s11367-015-0959-7

Alsema E, de Wild MJ (2005) Environmental impact of crystalline silicon photovoltaic module production. In: MRS Proc, vol 895. https://doi.org/10.1557/PROC-0895-G03-05

Apergis N, Payne JE (2010) Renewable energy consumption and economic growth: evidence from a panel of OECD countries. Energy Policy 38(1):656-660. https://doi.org/10.1016/j.enpol.2009. 09.002

Berylls Strategy Advisors (2018) Battery production today and tomorrow. Study of the battery production market, VII.

Bosch K (2010) Finanzmathematik, 7th edn. Oldenbourg, München (http://www.oldenbourg-link.com/doi/book/10.1524/9783486 599398.)

Bulach W, Schüler D, Sellin G, Elwert T, Schmid D, Goldmann D et al (2018) Electric vehicle recycling 2020: Key component power electronics. Waste Manag Res 36(4):311-320. https://doi.org/10. $1177 / 0734242 X 18759191$

Bundesministerium für -wirtschaftliche -Zusammenarbeit und Entwicklung (BMZ) (2017a) Grüne Bürgerenergie für Afrika

Bundesministerium für wirtschaftliche Zusammenarbeit und Entwicklung (BMZ) (2017b) Infoblatt AREI DE FINAL 2017

Chegere et al (2013) Poverty effects of fuel and food price changes in Tanzania

Cusenza MA, Guarino F, Longo S, Ferraro M, Cellura M (2019) Energy and environmental benefits of circular economy strategies: the case study of reusing used batteries from electric vehicles. J Energy Storage 25:100845. https://doi.org/10.1016/j.est.2019. 100845

East African Community (2017) Common external tariff. Annex 1 to the protocol on the establishment of the east African community customs UNION. EAC publication-harmonised commodity description and coding system

Eberhard A, Gratwick K, Kariuki L (2018) A review of private investment in Tanzania's power generation sector. J Energy South Afr. https://doi.org/10.17159/2413-3051/2018/v29i2a4389

Elf JL, Eke O, Rakgokong M, Variava E, Baliram Y, Motlhaoleng K et al (2017) Indoor air pollution from secondhand tobacco smoke, solid fuels, and kerosene in homes with active tuberculosis disease in South Africa. BMC Res Notes 10(1):591. https://doi.org/10. 1186/s13104-017-2892-2

Engel, Macht (2016) Comparison of lithium-Ion recycling processes for electric vehicle batteries. In: Yang H, Kong Z, Sarder MD (eds) Proceedings of the 2016 industrial and systems engineering research conference 
European Commission Joint Research Centre (2019) Photovoltaic geographical information system (PVGIS). Geographical assessment of solar resource and performance of photovoltaic technology. http://re.jrc.ec.europa.eu/pvgis/. Accessed 22 June 2019

Feldt T (2017) Wachsende Gesundheitsgefahr: Elektroschrott in Ghana. Flug Reisemed 24(04):185-189. https://doi.org/10.1055/ s-0043-116756

Fthenakis VM, Hyung Chul K, Alsema E (2008) Emissions from photovoltaic life cycles. Environ Sci Technol 42(6):2168-2174. https://doi.org/10.1021/es071763q

Fuchs et al (2012) Technologischer Überblick zur Speicherung von Elektrizität. Überblick zum Potenzial und zu Perspektiven des Einsatzes elektrischer Speichertechnologien

Gielen D, Boshell F, Saygin D (2016) Climate and energy challenges for materials science. Nature Mater 15(2):117-120. https://doi. org/10.1038/nmat 4545

Google Earth (2019) Kibumba Island, Tanzania. GPS coordinates: -1.9963205631042742, 31.7706 https://earth.google.com/web/. Accessed 19.12.2019.

Hannan MA, Lipu MSH, Hussain A, Mohamed A (2017) A review of lithium-ion battery state of charge estimation and management system in electric vehicle applications: challenges and recommendations. Renew Sustain Energy Rev 78:834-854. https://doi.org/ 10.1016/j.rser.2017.05.001

IEA-International Energy Agency (2014a) Africa Energy Outlook, World energy outlook 2014. OECD

IEA-International Energy Agency (2014b) Sustainable energy for all 2013-2014: global tracking framework report: the world bank

IEA-International Energy Agency (2018a) Global EV outlook

IEA-International Energy Agency (2018b) World energy outlook. WEO-2018-executive summary-English

IEA-International Energy Agency (2018c) World energy outlook 2018 https://data.worldbank.org/indicator/EG.ELC.ACCS.UR. ZS?end $=2016 \&$ locations $=$ TZ\&start $=1990 \&$ view $=$ chart. Accessed 26.08.2019

International Renewable Energy Agency (IRENA) (2017) Renewable power generation costs in 2017. https://www.irena.org/-/media/ Files/IRENA/Agency/Publication/2018/Jan/IRENA_2017_ Power_Costs_2018.pdf. Accessed 1 Apr 2019

Jiao N (2018) Second-Life Electric Vehicle Batteries 2019-2029. The Most Comprehensive Analysis on the Technologies, Players, Business Models and Opportunities of Second-Life Electric Vehicle Batteries. 2018. https://www.idtechex.com/tw/researchreport/second-life-electric-vehicle-batteries-2019-. Accessed 27 Aug 2019

Korthauer R (ed) (2018) Lithium-Ion batteries: basics and applications. Springer, Berlin, Heidelberg

Martinez-Laserna E, Gandiaga I, Sarasketa-Zabala E, Badeda J, Stroe D-I, Swierczynski M, Goikoetxea A (2018) Battery second life: hype, hope or reality? A critical review of the state of the art. Renew Sustain Energy Rev 93:701-718. https://doi.org/ 10.1016/j.rser.2018.04.035

Maschke C, Fastl H (2017) Schallwirkungen beim Menschen. In: Müller G, Möser M (eds) Schallwirkungen beim Menschen, vol 46. Springer, Berlin, Heidelberg, pp 1-30

Moner-Girona M, Ghanadan R, Solano-Peralta M, Kougias I, Bódis K, Huld T, Szabó S (2016) Adaptation of Feed-in Tariff for remote mini-grids: Tanzania as an illustrative case. Renew Sustain Energy Rev 53:306-318. https://doi.org/10.1016/j.rser.2015.08.055

Moner-Girona M, Solano-Peralta M, Lazopoulou M, Ackom EK, Vallve X, Szabó S (2018) Electrification of Sub-Saharan Africa through PV/hybrid mini-grids: reducing the gap between current business models and on-site experience. Renew Sustain Energy Rev 91:1148-1161. https://doi.org/10.1016/j.rser.2018.04.018

Mutuku, Mbithi (2017) What drives import flows, do import standards and verification for conformity matter? A panel gravity model for Kenya, Review Article, Res J Econ 1(2)

Naudé et al (2007) UNU policy brief 5
Nedjalkov A, Meyer J, Göken H, Reimer MV, Schade W (2019) Blueprint and implementation of rural stand-alone power grids with second-life lithium Ion vehicle traction battery systems for resilient energy supply of tropical or remote regions. Materials. https://doi.org/10.3390/ma12162642

Ogunjuyigbe ASO, Ayodele TR, Akinola OA (2016) Optimal allocation and sizing of PV/Wind/Split-diesel/Battery hybrid energy system for minimizing life cycle cost, carbon emission and dump energy of remote residential building. Appl Energy 171:153-171. https://doi.org/10.1016/j.apenergy.2016.03.051

Ohler A, Fetters I (2014) The causal relationship between renewable electricity generation and GDP growth: a study of energy sources. Energy Econ 43:125-139. https://doi.org/10.1016/j.eneco.2014. 02.009

Peters J, Sievert M (2016) Impacts of rural electrification revisited-the African context. J Dev Eff 8(3):327-345. https://doi. org/10.1080/19439342.2016.1178320

Podias (2018) Saslab final report 2018

Ponzano P (2018) European neighborhood and marshall plan with Africa: a federalist point of view. Fed Debate 31(2):6-10. https:// doi.org/10.2478/tfd-2018-0014

Romare, Dahllöf (2017) The life cycle energy consumption and greenhouse gas emissions from lithium-Ion batteries

Lal S, Raturi A (2012) Techno-economic analysis of a hybrid mini-grid system for Fiji islands. Int J Energy Environ Eng 3(10). https:// doi.org/10.1186/2251-6832-3-10

Scholvin S (2015) A new scramble for Africa? The rush for energy resources in sub-Saharan Africa. The international political economy of new Regionalisms series. Taylor and Francis, London

Scrosati B, Garche J (2010) Lithium batteries: status, prospects and future. J Power Sources 195(9):2419-2430. https://doi.org/10.1016/ j.jpowsour.2009.11.048

Szabó S, Bódis K, Huld T, Moner-Girona M (2011) Energy solutions in rural Africa: mapping electrification costs of distributed solar and diesel generation versus grid extension. Environ Res Lett 6(3):34002. https://doi.org/10.1088/1748-9326/6/3/034002

Tanzania High Commission Natural resources and mining in Tanzania. https://ke.tzembassy.go.tz/tanzania/category/natural-resources. Accessed 25 Jan 2019

TBS (2017) Pre-shipment verification of conformity. Tanzania bureau of standards. http://www.tbs.go.tz/index.php/services/category/ pre-shipment_verification_of_conformity. Accessed 24 Jan 2019

Thielmann et al (2015) Gesamt-Roadmap Lithium-Ionen-Batterien 2030

UNDP (2017) Human development reports. http://hdr.undp.org/en/ composite/HDI. Accessed 21 Jan 2019

UNFCCC (2015) Adoption of the paris agreement—paris agreement text English

United Nations (2018) Sustainable development. Division for sustainable development goals. https://sustainabledevelopment.un.org/ content/documents/17565PB18.pdf. Accessed 23 Dec 2018

U.S. Energy Information Administration (2013) IHS Economics; International Energy Statistics. https://www.eia.gov/international/ data/world. Accessed 23 Dec 2018

Vogler et al (2016) Bio- und Solarenergie Tansania. Zielmarktanalyse, April 2016. AHK - Delegation der deutschen Wirtschaft in Kenia

Waqas et al (2018) Assessment of carbon footprints in terms of co2 of diesel generator. In: Earth sciences Pakistan, pp 15-17

Wiedmann T, Minx J (2007) A definition of "carbon footprint". In: Ecological economics research trends. Nova Science Publ, New York, pp 1-11

Wolde-Rufael Y (2006) Electricity consumption and economic growth: a time series experience for 17 African countries. Energy Policy 34(10):1106-1114. https://doi.org/10.1016/j.enpol.2004.10.008

Worldbank (2018) Data region sub Saharan Africa. https://data. worldbank.org/region/sub-saharan-africa. Accessed 23 Dec 2018

Zhang C, Wei Y-L, Cao P-F, Lin M-C (2018) Energy storage system: current studies on batteries and power condition system. Renew Sustain Energy Rev 82:3091-3106. https://doi.org/10.1016/j.rser. 2017.10.030 